\title{
The Influence of Application Government Internal Control System, Asset Management and Human Resources Competencies to Financial Accountability
}

\author{
Sabrina Nur Fhadillah \\ Department of Accounting - Faculty of Economics and Business \\ Universitas Padjadjaran \\ Ivan Yudianto \\ Department of Accounting - Faculty of Economics and Business \\ Universitas Padjadjaran
}

\begin{abstract}
This research aims to examine the influence of the application of government internal control system, asset management, and human resources competencies toward financial accountability of Bandung Municipal Government. Survey research was conducted in 27 Local Work Unit of Bandung Municipal. This research using the descriptivequantitative method by spreading a questionnaire to every Local Work Unit as much as 55 questionnaires. The respondent of this research is an auditor, staff of finance, and asset management. Method of data analysis used by this research is multiple linear regression that assisted with SPSS software. The result of this research showed that: (1) The application of Government Internal Control System significantly influence financial accountability of Bandung Municipal Government with 0,016640 percentage or $1,166 \%$; (2) Asset management significantly influence financial accountability of Bandung Municipal Government with 0,423200 percentage or 42,32\%; (3) The human resource competencies significantly influence financial accountability of Bandung Municipal Government with 0,356208 percentage or $35,62 \%$. Also, the simultaneous influence of government internal control system, asset management, and human resources competencies to financial accountability are $79.6 \%$, and amount of the rest is $20,4 \%$ affected by another factor outside of this research. In Local Work Unit, Bandung municipal still need supervision about accountability and recording to local asset and improve commitment leader. With the expected improvements in the government's financial statements, the financial statements of Bandung municipal could be better in 2017.
\end{abstract}

Keywords : Application of government internal control system; Asset management; Human resources competencies; Financial accountability.

\section{Introduction}

The Law No.17 Year 2003 on State Financial Management and Law No.32 Year 2004 on Granting Authority From The Central Government To Local Government are a form of reform in the financial sector. Providing authority from the central government to local governments is expected to assist in improving the welfare of the community and also can improve the performance of the local government itself.

With the granting of such authority, in 2004 the government passed Law No.33 Year 2004 on Financial Balancing Of Central Government And Local 
Government which became known as the era of local autonomy due to fundamental changes in governance and financial relations between the central and local governments. As one form of accountability of local governments over the granting of such powers as outlined in Law No.12 Year 2008, on the need to prepare local financial statements

Table 1. The opinion of Bandung Municipal Government Financial Statements

\begin{tabular}{ll}
\hline Year & Opinion \\
\hline 2012 & Qualified \\
2013 & Qualified \\
2014 & Qualified \\
2015 & Qualified \\
2016 & Qualified \\
\hline
\end{tabular}

The financial statements of Bandung Municipal still get a qualified opinion because there are still problems that found The Audit Board Of Republic Indonesia findings at the time of the audit.

Financial reporting also serves to increase the confidence of users about the probability of realizing an expectation under conditions of uncertainty, in addition to other functions of financial reporting is to change the decisions or behavior of users (Suwardjono, 2005:167-168), therefore it is essential to ensure accountability financial reporting mainly for the public sector.

Therefore, to improve the financial accountability of the government of Bandung, the application of internal control system of government, asset management, and human power effectively implemented in each Local Work Unit Bandung. This study aims to analyze the influence of the implementation of government internal control system, asset management, and human resources competencies to the financial accountability of the Bandung municipal government.

\section{Literature Review}

\section{Financial Accountability}

Mardiasmo (2009) explains the notion of public accountability as the obligation of the holder of the trustee (agent) to provide accountability, presenting, reporting, and all activities become his responsibility to the party giving the mandate (principal) who has the right to hold the accountability. Public accountability consists of two types: 1) accountability for higher fund management (vertical accountability), and 2) accountability to the public (horizontal accountability).

Then, Riyanto (2015) states that accountability is the obligation to give accountability or answer and explain the performance or accountability action in principle any village financial management activities should be accountable to the village community, in accordance with the laws and regulations that are important for security, fluency and reliability in the fullfledged village financial reporting, from planning to realization or implementation.

According to Government Regulation Number 60 Year 2008 on Government Internal Control System is an integral process of actions and activities undertaken continuously by the leadership and all employees to provide reasonable assurance on the achievement of organizational goals through effective and efficient activities, reliability of financial reporting, security of state assets, and compliance with laws and regulations

According to the Minister of Home Affairs Regulation no. 17 The year 2007 on 
Technical Guidance on the Management of Regional Goods, the definition of regional wealth is all goods purchased at the expense of the regional income or expenditure budget or legal gain.

Human resources competencies are the ability and characteristics of a civil servant who knows, skills, and attitudes required in the implementation of duties of his position, so that Civil Servants can carry out their duties professionally, effectively and efficiently. (Dewi and Yusrawati, 2015)

\section{Government Internal Control System and Financial Accountability}

In the journal Tuti Herawati (2014) states that if an internal control has been established then all operations, physical resources, and data will be monitored and under control, objectives will be achieved, risks become small, and the result will be more qualified. With the establishment of internal controls in the accounting system, the accounting system will produce more qualified accounting information (timely, relevant, accurate, and complete), and can be audited.

Mahmudi (2007:27) states to produce the necessary government financial statements. Information systems in the internal control process, the quality of financial statements that are not owned by the internal control system owned by the local government. In the financial statements which are the accountability required in Government Regulation Number 60 the Year 2008 on the Government Internal Control System.

Furthermore, the phenomenon of government financial statements quality in Indonesia is interesting to be studied further. This rationale stems from the fact that there are deviations found by the Audit Board of Republic Indonesia in the audit of government financial statements (Ida and Ni made, 2016), such as the findings of the audit of the financial statements of Bandung municipal government in 2016 still get a qualified opinion that the resulting asset management Bandung municipal that has not been good.

In addition to internal government control system factors and asset management that helps in the effort to support the accountability of financial statements that is the human resources competencies who manage it. According to Winidyaningrum (2009), the high quality of local government financial statements is also determined by how well the internal controls of local government institutions. Weak internal controls make it difficult to detect fraudulent /inaccurate accounting processes so that audit evidence obtained from accounting data becomes incompetent.

\section{Management Asset and Financial Accountability}

In the journal Anshari and Efriza (2016), the better the Local-Owned Assets will improve the quality of financial statements and make the financial statements more qualified and accountable. Furthermore, according to Anwar Nasution in Accounting Magazine of Indonesia (2008) on Anshari and Efrizal (2016), the management of state and land assets owned by the central government and local government is considered to be less orderly. It can be seen from the defect and proof of the rights of those assets. Less orderly recording impact on the fairness of asset reporting in the financial statements, riskprone, and prone to the recognition of assets by other parties that later became disputed.

Management of local-owned assets is part of the system, namely the accounting system that is a management information system. According to Hariningsih (2006:2), the system is planned to produce useful information for outsiders or within organizations. Wilkinson et.al. (2000:18) that quality information can produce quality financial reports as well. Reinforced by $\mathrm{M}$. Yusuf (2010:8) management of 
components that are important to realize better financial statements

\section{Human Resources Competence and Financial Accountability}

According to Wayan and Gusti (2017) states that human resources are an essential organizational element, which must be managed as well as possible in order to be able to contribute optimally in the effort to achieve organizational goals, one of which creates qualified financial statements. Management of human resources can be done by providing training in order to improve competence. Adequate human resource competence will be able to produce good quality financial statements.

According to Siti Zahrah et al. (2017) state that Evidence from the results of this study presents the fact that the human resources competencies and managerial have significant effect simultaneously to the quality of financial statements so as to provide an understanding that the ability of each individual is needed together to provide the best results based on the best ability possessed by individuals working in an organization.

These results are in line with the research of As Syifa (2014), Winidyanigrum (2009) and $\mathrm{Xu}$ (2003) in Siti Zahrah, et al (2017) which declare human resources, an essential factor in determining the quality of accounting information wherever technology and systems which has been very well designed will not work without the support of human resources competencies and should be controlled to run well.

According to Juita (2013), human resource is an essential organizational element, therefore must be ensured that these human resources must be managed as possible in order to be able to contribute optimally to achieve organizational goals. Management of human resources can be done by providing training in order to improve competence. Adequate human resource competencies will be able to produce quality financial reports. It is in line with previous research conducted by Wati et al. (2014), Rama \& Putra (2014), Surastiani (2015) states that the human resources competencies have a positive effect to the quality of financial statements.

\section{Hypothesis}

A hypothesis is a tentative conclusion that should be tested or proven to be true (Sekaran,2003). Based on the research problem, and a framework that has been stated previously, the research hypothesis can be formulated as follows:

\section{H1: Implementation of government internal control system has a positive effect on financial accountability Bandung Municipal Government. \\ $\mathrm{H} 2$ : Implementation of asset management has a positive effect on financial accountability Bandung Municipal Government.}

H3: Implementation of human resource competencies has a positive effect on financial accountability Bandung Municipal Government.

\section{Research Methods}

This research method focuses on the analysis of the application of the government internal control system, asset management, and human resource competencies to the financial accountability of the Bandung municipal government. Judging from the existence of variables and taking into account the objectives to be achieved from the results of this study, the descriptive research approach with research method is a quantitative method.

Unit analysis can be interpreted as something related to the focus or components studied; therefore focus on this research is the village. According to Sugiyono (2011:61), the population is a 
generalization local consisting of an object or subject that has certain qualities and characteristics applied by researchers to study and then draw conclusions. In this study, the population in question is 27 Local Work Unit in Bandung. Furthermore, in this study 27 Local Work Unit was sampled by researchers.

The method of analysis used in this research is multiple regression analysis with the effect for one dependent variable (Ghozali, 2011). The multiple regression model in this statement is as follows:

$$
\begin{aligned}
& \text { Explanation: } \\
& \mathrm{Y}=\text { quality of financial statements } \\
& \alpha=\text { constants } \\
& \beta 1=\text { regression coefficient of } \\
& \text { application of government } \\
& \text { internal control system } \\
& \beta 2=\text { regression coefficient of asset } \\
& \text { management } \\
& \beta 3=\text { regression coefficient of } \\
& \text { competence of human resources } \\
& \mathrm{X} 1=\text { variable implementation of the }
\end{aligned}
$$$$
\mathrm{Y}=\alpha+\beta 1 \mathrm{X} 1+\beta 2 \mathrm{X} 2+\beta 3 \mathrm{X} 3+\mathrm{e}
$$

$$
\begin{aligned}
\mathrm{X} 3= & \text { variable competence of human } \\
& \text { resources } \\
\mathrm{e} \quad= & \text { disturbing variable }
\end{aligned}
$$

\section{Result and Discussion}

The results of the validity test In the four variables in each item question shows that all items statement on each variable has a validity coefficient greater than 0.3 critical $r$, so the items are Government internal control system, asset management, resource competence human and financial accountability worthy to be used as a measuring tool in research.

Reliability test results show the reliability value of the statement on the questionnaire each of the variables studied greater than 0.6. These results indicate the items per item on the questionnaire reliably to measure variables Results> 0.6 can still be said reliable.

Based on the SPSS output obtained Sig. Normality test using the Kolmogorov Smirnov method of 0.967 , this p-value value is higher than alpha $(0.967>0.05)$, it can be concluded normally distributed residual data.

Table 2. Normality Test Results

One-Sample Kolmogorov-Smirnov Test

\begin{tabular}{|ll|r|}
\hline & & $\begin{array}{r}\text { Unstandardiz } \\
\text { ed Residual }\end{array}$ \\
\hline N & 27 \\
Normal Parameters & a,b & Mean \\
Most Extreme & Std. Deviation & .0000000 \\
Differences & Absolute & 2.76678013 \\
& Positive & .095 \\
Kolmogorov-Smirnov Z & Negative & .058 \\
Asymp. Sig. (2-tailed) & & -.095 \\
\hline
\end{tabular}

a. Test distribution is Normal.

b. Calculated from data. 
Heterokedastisitas test results from each image show that the points spread randomly, do not form a pattern. Also, the points spread both above and below the zeros on the Y-axis. It can be concluded that there are no heterokedastisitas on the regression model. The regression model is appropriate for later analysis. The multicollinearity test results show that the VIF value of each independent variable is below 10, i.e., the government internal control system $(\mathrm{X} 1)=1.048$, asset management (X2) 1.261 and human resource competence $(\mathrm{X} 3)=1.210$. Based on these results, it can be concluded that there is no multicollinearity among the independent variables in the model. $\mathrm{T}$

The results of multiple linear regression test presented based on the above output obtained contents and regression that can form multiple linear regression equation as follows: $\mathrm{Y}=-14,861$ $+0,076 \mathrm{X} 1+0,757 \mathrm{X} 2+0,893 \mathrm{X} 3$. The above equation can be interpreted as follows:

- $\mathrm{a}=-14,861$ means if applying Government Internal Control (X1), Asset Management (X2), Human Resources (X3) increases zero (0), then Financial Accountability (Y) will be worth $-14,861$ units;

- $\mathrm{b} 1=0.076$ means that if applying Government Internal Control (X1) increases unit units and other variables constant, then Financial Accountability (Y) will increase by 0.076 units;

- $\quad \mathrm{b} 2=0.757$ means if Asset Management (X2) increases one unit and the other variable is constant, then Financial Accountability (Y) will increase by 0.757 units;

- $\quad$ b3 $=0.893$ words if Human Resources (X3) increases one unit and other variable constants, then Financial Accountability (Y) will increase by 0.893 units

After the known value of $R$ of 0.892 , then it can be calculated by using the formula as follows: Coefficient of Determination $=(0,892) 2 \times 100 \%=79,6 \%$, Therefore, the obtained coefficient of determination of $76.6 \%$ which shows the meaning that the variable Application of Government Internal Control (X1), Asset Management (X2) and Human Resources (X3) simultaneous influence (together) of 79.6\% Financial Accountability (Y). While the rest of $20.4 \%$ influenced by other factors not observed in this study.

Partial percentage calculation results, it can be seen that the implementation of Government Internal Control (X1) gives a positive influence of 0.016640 or $1.166 \%$ to Financial Accountability (Y), Asset Management (X2) gives a positive influence of 0.423200 or $42.32 \%$ to Financial Accountability (Y) and Human Resources (X3) gives a positive effect of 0.356208 or $35.62 \%$ to Financial Accountability (Y).

\section{Effect Implementation of Government Internal Control System and Financial Accountability}

Based on the results of statistical analysis, it is found that the variables of implementation of government internal control system (X1) have more significant $\mathrm{t}$-count value than $\mathrm{t}$-table $(2.153>2.069)$ and the significance level smaller than 0.05 $(0.05>0.042)$, so this indicates that the variable implementation of government internal control system partially positive effect on financial accountability or in other words hypothesis (H1) accepted. It indicates that the better the quality of the government internal control system, the better the financial accountability.

\section{The Influence of Asset Management to Financial Accountability}

Based on the result of statistical analysis, it is found that the variable of Asset Management (X2) has more significant $\mathrm{t}$-count value than $\mathrm{t}$-table $(5,438$ 
$>2,069)$ and significance level smaller than $0.05(0.05>0.000)$. Then this matter indicates that the variable of Asset Management partially has a positive effect on financial accountability, or in other words, hypothesis (H2) accepted. It indicates that the better the asset management, the better the financial accountability.

Human Resource Competence and Financial Accountability. Based on the result of statistical analysis, it is found that the competence variable of human resources (X2) has a t-count value higher than t-table $(4.752>0.069)$ and the significance level smaller than 0.05 (0.05 > 0.000). Then this is hypothesis (H3) accepted. It indicates that the better the competence of human resources, the better the financial accountability.

\section{Conclusion and Recommendation}

\section{Conclusion}

From the result of calculation and analysis that has been done in the previous chapter, it can be concluded: Implementation of government internal control system has a positive influence on financial accountability at Bandung municipal government, with the percentage of influence of 0.016640 or $1.166 \%$. It shows that although there are still deficiencies in the implementation of government internal control system as there are still violations committed by Local Work Unit officials, it can be reduced by the external party Local Work Unit supervision that continues to monitor the performance of each Local Work Unit performance. The results are supported by the evaluation periodically, both quarterly and annual. Asset management has a positive influence on accountability of financial statements in Bandung municipal government, with a percentage of influence of 0.423200 or $42.32 \%$. It shows that the management of assets in each Local Work Unit has been managed quite well.

Human resources competencies have a positive influence on financial accountability at the government of Bandung municipal, with a percentage of influence equal to 0,356208 or $35,62 \%$. It shows that the human resources competencies in each Local Work Unit have been good enough.

\section{Recommendation}

Based on the results of research that has been discussed and concluded, suggestions and implications of research results as follows: Complete survey methods with interviews to increase the seriousness and awareness of respondents in answering all the questions that are in the questionnaire. Also, to reduce the subjectivity of the respondents that could lead to the results of research to be susceptible to the bias of respondents' answers.

If subsequent research on the financial accountability of local governments may be able to add other analytical factors not analyzed in this research. Such as internal control factors, population development factors, and low educational level and other factors. 


\section{References}

Agung, Dayu. SistemPengendalian Internal Pemerintah. Available at (https://www.slideshare.net/fendria uriga/sistem-pengendalian-internpemerintah) Diakses 7 September 2017, 09:31 WIB

Akuntabilitas Publik (Accountability), Available at (http://keuanganlsm.com/akuntabili tas-publik-accountability/) Diakses 16 Oktober 2017, 17:41 WIB

Ali.Y.H Sosialisasi-SPIP. Available at (https://www.slideshare.net/aliyudh i_h/sosialisasi-spip) Di akses 7 September 2017, 09:30

Anshari dan Efrizal. 2016. Pengaruh Pengelolaan Barang Milik Daerah Terhadap Kualitas Laporan Keuangan Pemerintah Kota Padang.

Arikunto, Prof.Dr. Suharsimi. 2005. Manajemen Penelitian. Jakarta. PT.Rineka Cipta.

Azlan, dkk. Pengaruh Kualitas Sumber Daya Manusia, Pemanfaatan Teknologi Informasi, Pengendalian Intern Akuntansi,dan Pengawasan Keuangan Daerah Terhadap Keandalan Laporan Keuangan Daerah Pada Skpd Pemerintah Kabupaten Lombok Timur. Jurnal Akuntansi.

Byars, Lloyd L; Rue, Leslie W, (2003). Human Resource Management, 7 edition, Mcgraw-Hill Irwin, New York

Dantes, Prof.Dr.Nyoman. 2012. Metode Penelitian. Yogyakarta. CV.Andi Offset.
Dessler, Gary. (2004).A framework for human resource management. Global Edition. Prentice-Hall. New Jersey.

Dewi dan Yusrawati. 2015. Pengaruh Kompetensi Sumber Daya Manusia dan Penerapan Sistem Akuntansi Keuangan Daerah Terhadap Kualitas Laporan Keuangan Daerah Pada Satuan Kerja Perangkat Daerah (Skpd)Kabupaten Empat Lawang Sumatera Selatan. J. Ekonomi.Vol.24

Heppy dan Andy.2017. Pengaruh Desentralisasi Fiskal, Sistem Pengendalian Internal dan Kinerja Pemerintah Daerah Terdahap Akuntabilitas Laporan Keuangan.Riset Akuntansi dan Keuangan 2(2).

Herawati, Tuti. 2014. Pengaruh Sistem Pengendalian Intern Terhadap Kualitas Laporan Keuangan (Survei Pada Organisasi Perangkat Daerah Pemda Cianjur).Vol XI, No.1.

http://bpkad.bekasikota.go.id/2016/11/07/p engelolaan-aset-daerah/) diakses 20 september 2017, 14:20 WIB. Pengelolaan Aset Daerah.

http://news.detik.com/berita-jawabarat/3227237/ridwan-kamil-soalaset-yang-buat-bandung-belumwtp/komentar) diakses 15 september 2017, 12:30 WIB. Ridwan Kamil: Soal Aset Yang Buat Bandung Belum WTP

http://pemerintah.net/sistem-pengendalianintern-pemerintah/) $\quad$ Di akses 7 September 2017, 09:32 WIB. Pemerintah, Net. Sistem 
Pengendalian

Intern

Pemerintah(SPIP)

http://www.bpkp.go.id/spip/konten/400/Se

kilas-SPIP.bpkp)diakses 15

september 2017, 12:24 WIB.

Sekilas SPIP

http://www.kppt.baliprov.go.id/id/SPIP--

Paradigma-Baru-Pengendalian-

Pemerintahan) diakses 10 Oktober 2017, 10:15WIB

https://www.merdeka.com/peristiwa/banya k-bangunan-belanda-bermasalah-

bikin-bandung-raih-wdp-dari-

bpk.html) diakses 15 september 2017, 12.24 WIB. Banyak BangunanBelanda Bermasalah,

Bikin Bandung Raih WDP dari BPK,

https://www.merdeka.com/peristiwa/kotabandung-kembali-mendapat-opiniwdp-dari-bpk.html) diakses 15 september 2017, 12:45WIB. Kota Bandung KembaliMendapatOpini WDP dari BPK

I Wayan dan I Gusti. 2017. Pengaruh Efektivitas Penerapan Sap, Kompetensi Sdm, dan Spi Pada Kualitas Laporan Keuangan Pemerintah Kabupaten Bangli. J. Akuntansi.Vol.21.1.

Ichlas, Muhammad; Basri, Hasan; dan Arfan, Muhammad. 2014. Pengaruh Penerapan Standar Akuntansi Pemerintahan, Sistem Pengendalian Intern Pemerintah Dan Aksesibilitas Laporan Keuangan Terhadap Akuntabilitas Keuangan Pemerintah Kota Banda Aceh. J. Magister Akuntansi Vol 3 No 4.

Ida dan Ni Made. 2016. Pengaruh Sumber Daya Manusia, Sistem Pengendalian Intern, Pemahaman Basis Akrual Terhadap Kualitas
Laporan Keuangan Daerah. J. Akuntansi. Vol.16.2.

John, dkk. 2015. Pengaruh Optimalisasi Manajemen Aset Daerah Terhadap Kualitas Laporan Keuangan Pemerintah Kota Makassar.J. Administrasi Negara.

Karmila; Amries Rusli Tanjung;Dan Edfan Darlis.Pengaruh Kapasitas Sumber Daya Manusia, Pemanfaatan Teknologi Informasi, Dan Pengendalian Intern Terhadap Keterandalan Pelaporan Keuangan Pemerintah Daerah(Studi Pada Pemerintah Provinsi Riau) .J.Magister Akuntansi.Vol 9, No.1

Mardiasmo. 2009. Akuntansi Sektor Publik. Yogyakarta. Andi

Masyhur, Mirza. Pengaruh Penyajian Laporan Keuangan Daerah, Aksesibilitas Laporan Keuangan Daerah Dan Pengendalian Internal Terhadap Transparansi Dan Akuntabilitas Pengelolaankeuangan Daerah Kota Dumai. J.Ekonomi. Vol.4, No1.

Nur, dkk. Pengaruh Penyajian Dan Aksesibilitas Laporan Keuangan Serta Sistem Pengendalian Intenal Pemerintah Terhadap Transparansi dan Akuntabilitas Pengelolaan Keuangan Daerah. Jurnal Akuntansi 2 (2).

Oktaviana. 2010. Pengelolaan Aset Daerah Berkaitan Opini Disclaimer BPK di Kabupaten Tojo Una Una di Sulawesi Tengah. Makalah Tesis Universitas Gajah Mada.

Praturan Mendagri Dalam Negeri Republik Indonesia No.17 Tahun 2007, tentang Pedoman Pengelolaan Barang Milik Daerah. 
Peraturan Pemerintah Republik Indonesia Nomor 38 Tahun 2008 tentang pengelolaan barang milik negara/daerah

Peraturan Pemerintah Republik Indonesia Nomor 60 Tahun 2008.tentang Sistem Pengendalian Internal Instansi Pemerintah, BPKP.

Peraturan Pemerintah Republik Indonesia Nomor 71 Tahun 2010, tentang Standar Akuntansi Pemerintahan.

Peraturan Menteri Dalam Negeri Republik Indonesia Nomor 4 Tahun 2008, tentang Pedoman Pelaksanaan Reviu Atas Laporan Keuangan Pemerintah Daerah

Peraturan Menteri Dalam Negeri Republik Indonesia Nomor 13 Tahun 2006, tentang pengelolaan keuangan daerah

Moh Nazir. 2005. Metode Penelitian. Bogor-Ciawi. Ghalia Indonesia.

Putu, dkk. 2014. Pengaruh Pengendalian Internal, Value For Money, Penyajian Laporan Keuangan Dan Aksesibilitas Laporan Keuangan Terhadap Akuntabilitas Pengelolaan Keuangan (Studi Empiris Pada Skpd Di Pemerintahan Daerah Kabupaten Klungkung).Jurnal Akuntansi. Volume 2, No.1.

Ratna Wijayanti. 2017. Pengaruh Kompetensi Sdm Dan Implementasi Akuntansi Akrual Terhadap Kualitas Laporan Keuangan Daerah. Jurnal Ilmu dan Riset Akuntansi.Volume 6, Nomor 3.

Siti, Dkk. 2017. Pengaruh Kompetensi Sumberdaya Manusia Dan Manajerial Terhadap Kualitas
Laporan Keuangan (Survey Pada

Dppkad Kabupaten Buol).J.

Katalogis. Volume 5 No 3

Sugiyono. 2011. Metode penelitian kuantitatif kualitatif dan R\&D. Bandung: alfabeta

Sugiyono. 2012. Metode Penelitian Bisnis.Bandung: CV. Alfabeta

Susetyo, Budi. 2010. Statistika Untuk Analisis Data Penelitian. Bandung :Refika Aditama

Suwardjono, 2005. TeoriAkuntansi: Perekayasaan Pelaporan Keuangan. Edisi Ketiga, BPFE, Yogyakarta.

Teuku, dkk. 2015. Pengaruh Penerapan Sistem Pengendalian Intern Dan Penerapan Prinsip Pengelolaan Keuangan Daerah Terhadap Kualitas Laporan Keuangan Pemerintah Daerah Kabupaten Aceh Barat 1) (Studi Pada Skpd Pemerintah Daerah Kabupaten Aceh Barat). Jurnal Magister Akuntansi.Vol.4 No.1.

Undang-Undang RI No.12 Tahun 2008, tentangpemerintah daerah

\begin{tabular}{ccr} 
Undang-Undang & RI & No.17 \\
Tahun2003 & ,tentangKeuangan \\
Negara & & \\
& & No.32 \\
Undang-Undang & RI & ,tentangPemerintah \\
Tahun2004 & Daerah & \multicolumn{2}{c}{}
\end{tabular}

Undang-Undang RI No.33 Tahun 2004 ,tentang Perimbangan Keuangan antara PemerintahPusatdanPemerintah Daerah

Warren, Carl S., dan James M. Reeve, 2004. Financial Accounting For Future Business Leaders, South Western, USA. 
Wiraputri, Maya Maulidia. 2012. PengaruhPengelolaanBarangMilik Daerah Terhadap Akuntabilitas Dengan Kualitas Laporan Keuangan Sebagai Variabel Intervening (Studi Kasus Pemerintah Kabupaten/Kota Ciayumajakuning, Subang, Karawang Dan Purwakarta).Skripsi
S1 Program SarjanaAkuntansi UPI. Bandung.

Yuliyanti, Dewi. 2015. Pengaruh Kompetensu Sumber Daya Manusia Terhadap Kualitas Pelayanan Jasa Dokumen Impor Di PT Sarana Publik Logistik Jakarta. Jurnal Administrasi Publik. 